Brit. J. industr. Med., 1964, 21, 294.

\title{
VOLATILIZATION OF MERCURY BY BACTERIA
}

\author{
BY \\ L. MAGOS,* A. A. TUFFERY, $\dagger$ and T. W. CLARKSON \\ From the Toxicology Research Unit and Laboratory Animals Centre, Medical Research Council \\ Laboratories, Carshalton, Surrey
}

(RECEIVED FOR PUBLICATION JULY 20, 1964)

\begin{abstract}
Volatilization of mercury has been observed from various biological media (tissue homogenates, infusion broth, plasma, urine) containing mercuric chloride. That micro-organisms were responsible was indicated by the finding that the rates of volatilization were highly variable, that a latent period often preceded volatilization, that toluene inhibited the process, and that the capacity to volatilize mercury could be transferred from one biological medium to another. Two species of bacteria when isolated and cultured from these homogenates were able to volatilize mercury. Two other bacteria, one of which was isolated from the local water supply, were also highly active. The volatile mercury was identified as mercury vapour. The importance of these findings in relation to the storage of urine samples prior to mercury analysis is discussed. $\rightarrow$
\end{abstract}

The determination of toxic compounds and their metabolites in biological materials is one of the methods frequently applied in both toxicological research and industrial hygiene practice. When a prompt determination is not possible, the samples must be stored, and great care is usually taken when organic substances are to be estimated. As inorganic compounds, especially heavy metals and their salts, are supposed to be resistant to biochemical and bacteriological attack, special care in storing specimens containing this is assumed to be unnecessary. Elkins (1959) states that, 'in the case of mercury addition of preservatives is not recommended since condition of the sample prior to digestion is immaterial, provided no sediment or precipitate adheres to the bottle, causing possible loss of mercury'. The results reported in the paper indicate that this advice must now be modified, at least in the case of inorganic mercury.

The present study resulted from a chance observation. Tissue homogenates containing added $\mathrm{HgCl}_{2}$ labelled with ${ }^{203} \mathrm{Hg}$ isotope lost radioactivity more rapidly than could be accounted for by the normal radioactivity decay (half-life $\mathbf{4 5}$ days) of this isotope. This report is concerned with a more detailed investigation into this phenomenon.

*Wellcome Trust Fellow.

$\dagger$ Present address: Department of Microbiology, School of Medicine, Perth, W. Australia.

\section{Methods}

Tissue homogenates were prepared from decapitated male Wistar rats (300-350 g.) using the apparatus of Aldridge, Emery, and Street (1960). The homogenate was centrifuged for $10 \mathrm{~min}$. at $800 \mathrm{~g}$, and the supernatant was decanted and diluted with sucrose EDTA solution $(103 \mathrm{~g}$. sucrose and $372 \mathrm{~g}$. of ethylene diaminetetra-acetic acid, disodium salt (EDTA), per litre of solution) to a final homogenate concentration of $10 \%$ (wet weight to volume). Further dilutions were made in tris buffer to a final concentration of $1 \%$ or $0.1 \%$. The tris buffer was prepared by dissolving $9.32 \mathrm{~g}$. of $\mathrm{KCl}, 1.82 \mathrm{~g}$. of tris (hydroxymethylamino) methane and $0.372 \mathrm{~g}$. of EDTA in $800 \mathrm{ml}$. of distilled water; the $p \mathrm{H}$ was adjusted to $7 \cdot 4$ with $\mathrm{HCl}$ and the volume made up to 1 litre. Other biological media were freshly voided human urine, citrated human plasma obtained from the local blood bank, and an infusion broth normally used for bacteriological work, prepared and sterilized according to Mackie and McCartney (1953). Dilutions of the broth, 1:10 and 1:100, were made with tris buffer. The urine was sterilized by Seitz filtration. Further details of the bacteriological techniques are given in the legend of Figure 3.

Radioactive mercury $\left({ }^{203} \mathrm{Hg}\right.$ isotope) was obtained from the Radiochemical Centre, Amersham as an aqueous solution of mercuric chloride or acetate of specific activity, $100 \mathrm{mc}$./g. Hg. The isotope was diluted in tris buffer which was added to the biological medium under study in the ratio $1 \mathrm{ml}$. of buffer to $9 \mathrm{ml}$. of medium. The radioactivity in the medium always exceeded 2,000 counts per minute per ml. Sufficient carrier mercuric chloride was added to the tris buffer to give a final concentration in the medium in the desired range $\left(10^{-4}\right.$ to $\left.10^{-7} \mathrm{M} \mathrm{HgCl}_{2}\right)$. 
One millilitre of the radioactive medium was added to glass test tubes of size $150 \mathrm{~mm}$. $\times 16 \mathrm{~mm}$. The tubes, sealed with 'Parafilm' $\ddagger$ were mounted on the turn-table of an automatic scintillation spectrometer $\S$ counting efficiency $40 \%$ and counted repetitively for varying periods of time from several hours to several days. Chemical concentrations of mercury in the tris buffer were measured by the method of Clarkson, Gatzy, and Dalton (1961).

\section{Results}

The data of Table 1 are taken from experiments originally intended to measure the binding of mercuric ion by kidney homogenates. The homogenate suspension $(0 \cdot 1 \%)$ containing various concentrations of added $\mathrm{Hg}^{++}$ion was dialysed for four hours at $4^{\circ} \mathrm{C}$. against a penicillamine solution $\left(8 \times 10^{-4} \mathrm{M}\right)$.

TABLE 1

LOSS OF MERCURY FROM KIDNEY HOMOGENATE

\begin{tabular}{l|c|c|c|c|c}
\hline & \multicolumn{1}{|c|}{$\begin{array}{c}\mathrm{HgCl}_{2} \\
(\mathrm{M} / 1)\end{array}$} & \multicolumn{3}{|c|}{$\%$ Remaining ${ }^{208} \mathrm{Hg}$} \\
Activity
\end{tabular}

These experiments, in which the problem of mercury volatilization was first encountered, illustrate two important aspects of this phenomenon. First, loss of radioactivity was observed from the homogenate but not from the penicillamine dialysate. The loss from the homogenate was not greatly influenced by the mercury concentration over the range studied $(5 \times$ $10^{-6}$ to $10^{-4} \mathrm{M} \mathrm{HgCl}_{2}$ ). Second, in all instances loss of mercury only began to take place after a latent period of at least 16 hours. As later results will illustrate, the latent period changes with experimental conditions.

Figure 1 illustrates the rate of loss of mercury from three samples of kidney homogenate. The three curves demonstrate the great variability in rates of loss of mercury under apparently identical experimental conditions. Furthermore, the curves have a characteristic shape, consisting of three phases: a latent period, a rapid fall, followed by a very slow decline.

The latent period, the requirement for the presence of tissue homogenate (Table 1), and the variability in the rate of loss of mercury in time and between

†Gallenkamp, Christopher Street, London, E.C.2.

$\S$ Model 450A, Packard Instrument Co., Chicago, Illinois.

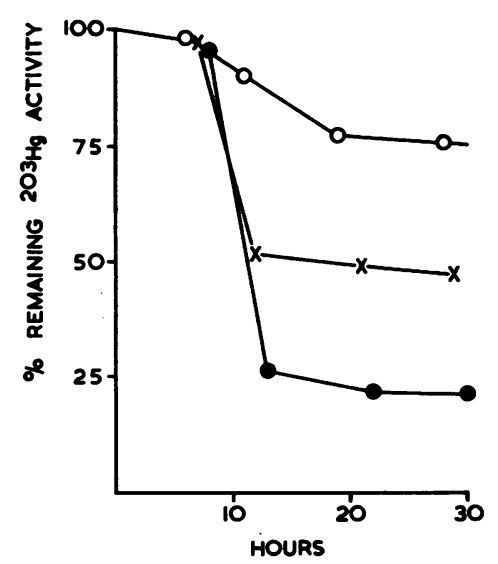

FIG. 1.-Volatilization of mercury from kidney homogenate. Three $1 \mathrm{ml}$. samples from a $1 \%$ kidney homogenate containing $10^{-6} \mathrm{M}$ $\mathrm{HgCl}_{2}$ were incubated at room temperature, and the loss in radioactivity was recorded.

samples of the same homogenates (Fig. 1) suggested that a micro-organism might be involved. To check this conclusion samples of homogenate already rapidly losing mercury were added to samples of sterile infusion broth containing radioactive $\mathrm{HgCl}_{2}$. An immediate volatilization of mercury was induced. The details of the experiment were as follows. A $1 \%$ kidney homogenate containing radioactive $\mathrm{HgCl}_{2}$ $10^{-5} \mathrm{M}$ was incubated for 24 hours. During this time $60 \%$ of the initial radioactivity had disappeared. At this stage $0.1 \mathrm{ml}$. samples containing 2,500 counts per 5 minutes were transferred to $1 \mathrm{ml}$. samples of (a) standard infusion broth, and dilutions equivalent to (b) $10 \%$ and $(c) 1 \%$ of the original each containing $10^{-5} \mathrm{M} \mathrm{HgCl}$ labelled with ${ }^{203} \mathrm{Hg}$ at 184,000 counts per 5 minutes per $\mathrm{ml}$. The three samples, standard broth, $10 \%$ and $1 \%$ dilutions, had lost respectively $16 \%, 56 \%$, and $63 \%$ of their initial activity 24 hours after infection with the homogenate. The control broths to which no homogenate was added lost $2 \%$ of their initial activity.

When toluene was added to samples of kidney homogenate the loss of mercury did not take place, providing further evidence that micro-organisms are involved. The results and experimental details are given in Table 2. Toluene must act by killing bacteria since the $0.1 \mathrm{ml}$. droplet of toluene added to the sample is not a physical barrier to the diffusion of mercury as indicated by the following experiment. A reducing agent (ascorbic acid) when added to solutions of $\mathrm{HgCl}_{2}$ in tris buffer induced a loss of mercury, but toluene does not block this process. For example, 24 hours after incubation of $\mathrm{HgCl}_{2}\left(10^{-5} \mathrm{M}\right)$ in the presence of ascorbic acid $\left(2 \times 10^{-2} \mathrm{M}\right)$ and toluene $(0.1 \mathrm{ml}$.) $61 \%$ of the initial activity had volatilized. 
TABLE 2

EFFECT OF TOLUENE ON THE VOLATILIZATION OF MERCURY*

\begin{tabular}{c|c|c}
\hline \multirow{2}{*}{$\mathrm{HgCl}_{2}$} & \multicolumn{2}{|c}{$\%$ Remaining Mercury } \\
\cline { 2 - 3 } & With Toluene & Without Toluene \\
\hline $10^{-4}$ & 94 & 65 \\
$10^{-5}$ & 96 & 60 \\
$10^{-6}$ & 96 & 71 \\
\hline
\end{tabular}

* $1 \mathrm{ml}$. samples of $1 \%$ rat kidney homogenates containing $\mathrm{HgCl}_{2}$ labelled with ${ }^{203} \mathrm{Hg}$ were incubated at room temperature. The table records the radioactivity lost after 66 hours in the presence and absence of $0.1 \mathrm{ml}$. of toluene.

Micro-organisms were isolated from homogenates which were rapidly losing mercury, and after subculture they were tested for their ability to volatilize mercury from sterile infusion broth. In addition micro-organisms from laboratory stock cultures were also tested. Table 3 divides the micro-organisms into three groups producing (1) a loss greater than $30 \%$ in 48 hours, (2) a measurable loss of less than $30 \%$, and (3) a mercury loss not significantly different from control values with sterile broth.

Four micro-organisms were isolated from con- taminated homogenates (Code A, B, G, and H), two of which (A and B) were capable of rapidly volatilizing mercury. Two other micro-organisms were also highly active, one isolated from the local water supply (C) and a stock culture of Pseudomonas pyocyanea (D). Table 3 also contains the result of tests to identify organisms (A, B, C, G, and H). The other organisms were from stock cultures of known identity.

It had been assumed that the loss of radioactivity from the test tubes was due to the volatilization of mercury, but it was possible that mercury was being precipitated and that absorption of the $\gamma$ radiation within the precipitate was responsible for the fall in radioactivity. Experiments were designed to detect volatile mercury and to determine the chemical form in which the metal is volatilized. A disc of filter paper impregnated with selenium disulphide $\left(\mathrm{SeS}_{2}\right)$ was placed across the mouth of the test tube and it was found that from 86 to $91 \%$ of the mercury lost from the homogenate was recovered in the $\mathrm{SeS}_{2}$ paper (Table 4). Selenium disulphide is used as a specific detector for mercury vapour (Jacobs, 1949).

TABLE 3

MICRO-ORGANISMS TESTED FOR THEIR ABILITY TO VOLATILIZE MERCURY*

\begin{tabular}{|c|c|c|c|}
\hline Code & $\begin{array}{l}\text { Activity } \\
\text { in Broth }\end{array}$ & Source & Identification \\
\hline $\mathbf{A}$ & ++ & $\begin{array}{l}\text { Laboratory contaminated } \\
\text { homogenate }\end{array}$ & $\begin{array}{l}\text { A gram-negative, non-motile, non-sporing rod, which does not produce oxidase, urease, } \\
\mathrm{H}_{2} \mathrm{~S} \text {, indole; MR-, VP+, growth in citrate }+ \text {; produces acid in litmus milk, acid } \\
\text { and gas in glucose, lactose, sucrose, maltose, mannite, dulcite, salicin, sorbitol, } \\
\text { glycerol, arabinose, starch; does not reduce } \mathrm{NO}_{3} \text { or liquefy gelatine; produces } \\
\text { catalase. Could be Klebsiella aerogenes except for absence of urease. }\end{array}$ \\
\hline B & ++ & $\begin{array}{l}\text { Laboratory contaminated } \\
\text { homogenate }\end{array}$ & $\begin{array}{l}\text { A gram-negative, motile, non-sporing rod; produces catalase, urease; produces acid and } \\
\text { gas from glucose, acid from sorbitol and glycerol; does not ferment lactose, sucrose, } \\
\text { maltose, mannite, dulcite, salicin, aesculin, arabinose or starch; MR +, VP-, } \\
\text { indole }+ \text {, citrate +; does not liquefy gelatine, alter litmus milk or produce oxidase. } \\
\text { Produces } \mathrm{H}_{2} \mathrm{~S} \text { in peptone water but only minute quantities in } 1 \% \text { broth. This is an } \\
\text { unidentified species of Proteus. }\end{array}$ \\
\hline $\mathbf{C}$ & ++ & Laboratory water supply & $\begin{array}{l}\text { A gram-negative, non-motile diplococcus; capsulate, optichi sensitive, yielding growth } \\
\text { on McConkey agar, also isolated from the laboratory water supply and the gut of } \\
\text { animals given such water; produces catalase and reduces nitrate; produces } \mathrm{H}_{2} \mathrm{~S} \text { in } \\
\text { peptone water but only minute quantities in } 1 \% \text { broth; ferments no sugar tested; } \\
\mathrm{MR}-\mathrm{VP}-\text {, indole-, citrate }-, \text { gelatine not liquefied, does not produce oxidase. } \\
\text { It is difficult to classify this organism. }\end{array}$ \\
\hline $\mathbf{D}$ & ++ & Stock & Pseudomonas pyocyanea. Conforms to the accepted criteria for the species. \\
\hline $\mathbf{E}$ & + & Stock & Staphylococcus aureus. Conforms to the accepted criteria for this species. \\
\hline $\mathbf{F}$ & + & Stock & Salmonella typhymurium. Conforms to the accepted criteria for this species. \\
\hline G & - & $\begin{array}{l}\text { Laboratory contaminated } \\
\text { homogenate }\end{array}$ & $\begin{array}{l}\text { Identical with the diplococcus described above (code } \mathrm{C} \text { ) but produces } \mathrm{H}_{8} \mathrm{~S} \text { in } 1 \% \\
\text { broth. }\end{array}$ \\
\hline $\mathbf{H}$ & - & $\begin{array}{l}\text { Laboratory contaminated } \\
\text { homogenate }\end{array}$ & Identical with the proteus (?) described above (code $B$ ) but produces $\mathrm{H}_{2} \mathrm{~S}$ in $1 \%$ broth. \\
\hline $\mathbf{I}$ & - & Stock & Bacillus subtilis. Conforms to accepted criteria for this species. \\
\hline $\mathbf{J}$ & - & Stock & Escherichia coli. Conforms to accepted criteria for this species. \\
\hline $\mathbf{K}$ & - & Stock & Klebsiella aerogenes. Conforms to the accepted criteria for this species. \\
\hline $\mathbf{L}$ & - & Stock & forms to the accepted criteria for this species. \\
\hline
\end{tabular}

*Activity was measured as follows: $1 \mathrm{ml}$. volumes of sterile infusion broth containing $10^{-5} \mathbf{M ~} \mathbf{H g C l}_{2}$ were inoculated with one drop (approximately $0.01 \mathrm{ml}$.) of a $6 \frac{1}{2}$ hour peptone water culture. Micro-organisms producing a volatilization in 48 hours greater than $30 \%$ are labelled ++ , less than $30 \%+$, and no activity -.

MR = methyl red test; VP= Voges-Proskauer reaction. 
TABLE 4

COLLECTION OF VOLATILE MERCURY ON SELENIUM DISULPHIDE*

\begin{tabular}{c|c|c|c|c}
\hline Activity in Homogenate & $\begin{array}{c}\text { Net Loss } \\
\text { (cts/5 min.- }\end{array}$ & $\begin{array}{c}\text { Activity in } \\
\begin{array}{c}\text { Initial } \\
\text { Se Paper } \\
\text { (cts/5 min.) }\end{array}\end{array}$ & $\begin{array}{c}\text { After } 24 \text { min. }^{-1} \text { ) } \\
\text { (cts/5 min.-1) }\end{array}$ & $\begin{array}{c}\text { Recovery in } \\
\text { Se Paper } \\
\text { (\%) }\end{array}$ \\
\hline 153,000 & 93,300 & 59,800 & 51,300 & 86 \\
152,000 & 93,600 & 58,600 & 53,500 & 91 \\
\hline
\end{tabular}

*0.1\% kidney homogenates containing $10^{-6} \mathrm{HgCl}_{2}$ were inoculated with a diplococcus (Code $\mathrm{C}$, Table 3 ) and placed in test tubes $(150 \mathrm{~mm}$. $\times 16 \mathrm{~mm}$.). Whatman no. 1 filter paper coated with SeS, was sandwiched between two sheets of parafilm and pressed against the mouth of the test tube.

The volatilization of mercury from human urine is illustrated in Figs. 2 and $\mathbf{3}$ which are included to demonstrate the importance of this phenomenon in industrial hygiene.

The volatilization from urine can be prevented or reduced by the addition of toluene. A comparison of the upper two curves of Fig. 3 indicates that toluene is capable of preventing completely a loss of mercury from urine subjected to chance contamination in the laboratory. However, a species of diplococcus ((C) Table 3) isolated from the local water supply was the most active species tested, and when urine samples were given a massive infection of this diplococcus, toluene did not prevent an early loss of mercury but very much reduced the overall loss (Fig. 3, lower two curves).

\section{Discussion}

From a theoretical point of view these findings raise many questions on the mechanism whereby micro-organisms volatilize mercury. The capacity to convert ionic mercury to the volatile metallic form may be associated with specific properties of the micro-organism, such as its resistance to mercury, or the reducing power of some of the metabolites it produces. Other organisms may fail to grow in the presence of mercury or produce metabolites that inhibit the volatilization of mercury. For example, in the few species so far studied (Table 3), none of the bacteria which produced appreciable quantities of $\mathrm{H}_{2} \mathrm{~S}$ in the medium were capable of volatilizing mercury. Booer (1944) has reported that a microorganism producing $\mathrm{H}_{2} \mathrm{~S}$ inhibited the volatilization of mercury from soil. These and other questions remain for future study.

From a practical viewpoint the possibility of loss by volatilization clearly presents a serious hazard to the accurate analysis for inorganic mercury of such biological material as tissue homogenates, plasma, and urine. Losses of mercury amounting to $75 \%$ in less than 24 hours may take place from homogenates

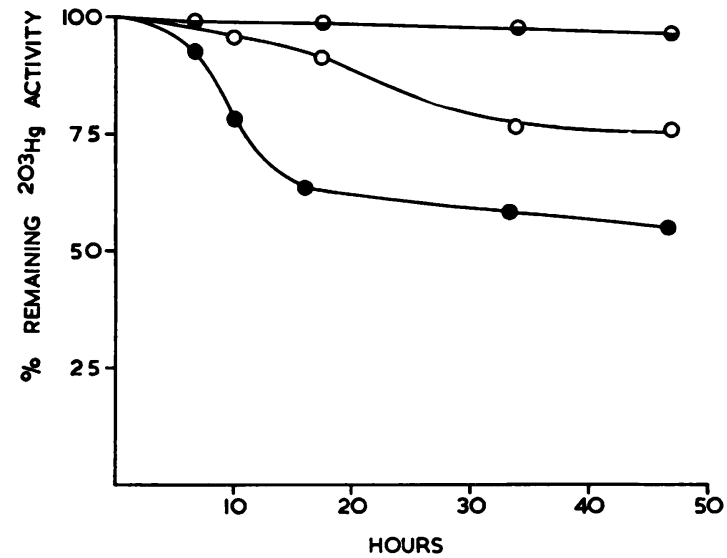

FIG. 2.-Volatilization of mercury from urine. One ml. volumes of sterile human urine containing $10^{-5} \mathrm{M} \mathrm{HgCl}_{3}$ were inoculated with one drop (approximately $0.02 \mathrm{ml}$.) of a $6 \frac{1}{2}$-hour peptone water culture containing micro-organisms. A sterile urine sample containing $0.1 \mathrm{ml}$. of toluene served as control. $\odot-\Theta$ control and Proteus (code $H$, Table 3 ).

$\bigcirc-\bigcirc$ Klebsiella aerogenes (code A, Table 3).

- diplococcus (code C, Table 3).

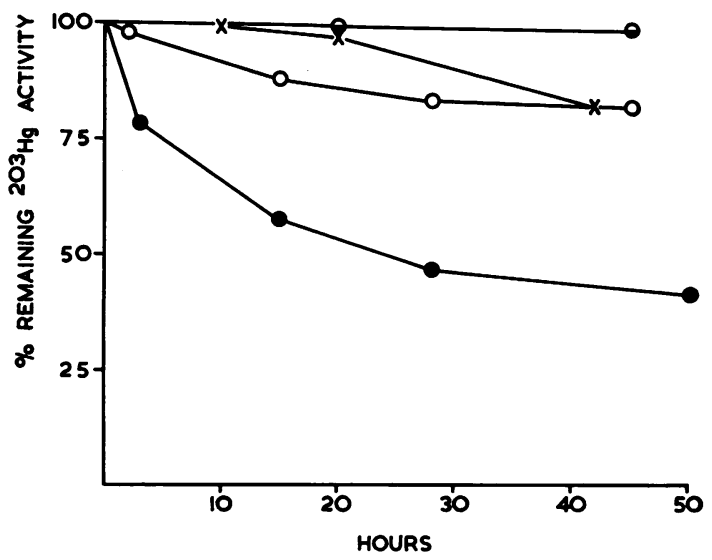

Fig. 3.-Effect of toluene in the volatilization from urine. All urine contained $10^{-5} \mathrm{M} \mathrm{HgCl}_{2}$.

$\times-x$ freshly voided non-sterile human urine.

$\checkmark-\ominus$ freshly voided non-sterile human urine plus $0.1 \mathrm{ml}$. toluene.

- freshly voided non-sterile human urine plus diplococcus (code C, Table 3).

$\bigcirc-\bigcirc$ freshly voided non-sterile human urine plus diplococcus $+0.1 \mathrm{ml}$. toluene.

infected by chance contamination in the laboratory (Fig. 1).

Urine is the biological fluid most frequently taken for mercury analysis in the control of mercury exposure in industry. Figure 3 records mercury volatilization for a concentration of $\mathrm{HgCl}_{2}$ in urine of $10^{-5} \mathrm{M}$, but similar results were obtained with concentrations of $\mathrm{HgCl}_{2}$ down to $10^{-7} \mathrm{M}$, thus including 
the range observed $\left(1 \cdot 1\right.$ to $\left.13.5 \times 10^{-6} \mathrm{M}\right)$ in the urine of workmen exposed to mercury (Elkins, 1959). The danger of contamination is obvious, but hitherto no special precautions have been taken to sterilize urine samples collected for mercury analysis (Elkins, 1959). Indeed volatilization of mercury from infected urine samples may be one of the causes of the wide variability in concentrations of mercury in urine samples from equally exposed workers (Neal et al., 1941).

We should like to acknowledge the excellent technical assistance given by Messrs. R. Corbett and R. Lock.

\section{REFERENCES}

Aldridge, W. N., Emery, R. C., and Street, B. W. (1960). Biochem. J., 77, 326.

Booer, J. R. (1944). Ann. appl. Biol., 31, 340.

Clarkson, T. W., Gatzy, J., and Dalton, C. (1961). AEC Research and Development Report, UR-582.

Elkins, H. B. (1959). The Chemistry of Industrial Toxicology, 2nd ed. John Wiley, New York.

Jacobs, M. B. (1949). The Analytical Chemistry of Industrial Poisons, Hazards, and Solvents, 2nd ed., p. 227. Interscience Publishers, New York.

Mackie, T. J., and McCartney, J. E. (1953). Handbook of Practical Bacteriology, 9th ed., p. 149 . Livingstone, Edinburgh and London.

Neal, P. A., et al. (1941). Mercurialism and its Control in the Felt-hat Industry. Public Health Bull. No. 263. Washington. 